\title{
Urea and deuterium-oxide spaces in man
}

\author{
BY M. W. B. BRADBURY \\ Nuffield Department of Clinical Biochemistry, The Radcliffe Infirmary, Oxford
}

(Received 19 July 1960-Revised 6 February 1961)

Urea has been used as an agent for the determination of total body water in man from time to time over the last I4 years (Steffensen, I947; McCance \& Widdowson, 1951; Pawan, 1954). Although it is claimed that the values obtained do in fact represent total body water and that variations in body water may be assessed by making repeated estimations of the urea space, little work has been done to confirm these assumptions. The urea method has given values for total body water similar to those obtained by desiccation in cats (Eggleton, I95 I) and similar to those obtained with antipyrine in man (Pawan, 1954; Srikantia \& Gopalan, 1957), but the best standard of comparison in living man must be with a dilution method using water labelled with one of the isotopes of hydrogen.

A technique for using urea and a method for calculating the urea space are presented. A study has been made of the variation which occurs between the urea space and the deuterium-oxide space determined simultaneously in the same subject. All the subjects were healthy members of the hospital or laboratory staff, except for J.E. who was an out-patient about to begin dieting for obesity; apart from being overweight, he was healthy.

\section{EXPERIMENTAL}

Measurement of urea space. The subjects took a low-protein meal the night before and fasted on the morning of the test. The bladder was emptied, the time noted, and a sample of venous blood collected. Immediately $50 \mathrm{ml}$ of a solution of urea (about $30 \%, \mathrm{w} / \mathrm{v}$ ) were injected intravenously over $3-5 \mathrm{~min}$. The urea solution was made up directly before use from sterile vacuum-dried urea and a solution of invert sugar ( $10 \%, w / v)$, both obtained from Baxter Laboratories Ltd. The injection was made into an antecubital vein with the forearm raised slightly above the horizontal to prevent possible backflow and stagnation of the hypertonic urea in smaller distal vessels. Generally blood samples were taken 2,3 and $4 \mathrm{~h}$ later. The bladder was emptied $5 \mathrm{~min}$ after the collection of each blood sample. The complete sample of urine was kept and its volume measured.

The injected urea solution, the serums and the urines were analysed in duplicate for urea by microdiffusion, the urea solution and urine being suitably diluted first. The chemical method was the urease-boric-acid-hydrochloric-acid procedure of Conway (I947). The ammonia content of the urines was allowed for by the use of blanks containing no urease. 
The urea space was calculated in the following way, which is based on the method of Steffensen (1947).

Let

$V$ be volume of distribution of urea (1.),

$u$ rise in serum urea concentration $(\mathrm{g} / \mathrm{l}$.$) ,$

$D$ weight of urea injected (g),

$P \quad$ total weight of urea excreted $(\mathrm{g})$,

$k$ production of urea per unit time $(\mathrm{g} / \mathrm{min})$,

$t$ time after collection of first urine specimen $(\mathrm{min})$.

Then

$$
V u=D-P+k t \text {, }
$$

or

$$
\frac{D-P}{u}=V-(t / u) k \text {. }
$$

If production of urea in the body proceeds at a constant rate, and if steady-state conditions exist at the time of each set of readings, then $(D-P) / u$ may be plotted against $t / u$ and a straight line obtained. The intercept with the $(D-P) / u$ axis will represent the urea space, and the slope of the line the production of urea by the body. Since $V$ represents a volume of water but serum is used for the determination of urea, the value obtained must be multiplied by 0.93 to allow for the fact that serum contains on the average $93 \%$ water.

Measurement of deuterium-oxide space. Immediately after the subject had received urea intravenously, a known volume of deuterium oxide was given orally. The deuterium oxide contained $99^{\circ} 76 \mathrm{~g}^{2} \mathrm{H}_{2} \mathrm{O} / \mathrm{roo} \mathrm{g}$ and was obtained from Norsk Hydro-elektrisk Kvaelstofaktieselskab. The volume given varied between 70 and $100 \mathrm{ml}$, so that the concentration in the serum was between 0.15 and $0.25 \mathrm{ml} / \mathrm{ro0} \mathrm{ml}$. The concentration of deuterium oxide in the serum taken at 2,3 and $4 \mathrm{~h}$ was estimated. The technique and apparatus used have been fully described and illustrated (Cohn, 1946; Schloerb, Friis-Hansen, Edelman, Sheldon \& Moore, 195I). After the double distillation of I $\mathrm{ml}$ samples of the serum under diminished pressure, the time of fall of drops of the final distillate in redistilled $o$-fluorotoluene was measured. The column of $o$-fluorotoluene was contained in a vertical glass tube ( $\mathrm{I} \mathrm{cm}$ in diameter). This tube was surrounded by a second wider tube $(2 \cdot 5 \mathrm{~cm}$ in diameter) containing water. Both were immersed in a water-bath maintained at $26.8^{\circ}$. The temperature variation during a run of estimations was considered to be not greater than $\pm 0.002^{\circ}$. Drops of the distillate and drops of standard solutions of deuterium oxide, measuring ro $\mu$, were delivered from an Agla micrometer syringe (Burroughs Wellcome and Co.). The time of fall of the drops between two marks ( $15 \mathrm{~cm}$ apart) was measured with a stop-watch reading to $0.1 \mathrm{sec}$. The mean time of fall of four drops of each distillate was compared with the mean time of fall of four drops of standard solutions of deuterium oxide (usually 0.20 and $0.25 \mathrm{ml} / 100 \mathrm{ml}$ ). Both standard solutions were examined in this way on each occasion directly before and after each unknown. The reciprocal of the time of fall of a drop is directly proportional to the content of deuterium oxide. Thus the deuterium-oxide content of unknown distillates was readily calculated.

The deuterium-oxide space was obtained by dividing by the concentration found the volume of deuterium oxide given less the amount excreted, the final value being 
the mean of those at 3 and $4 \mathrm{~h}$. A steady state had always been attained by $3 \mathrm{~h}$, but in some subjects had not been reached by $2 \mathrm{~h}$ (Table $\mathrm{r}$ ). The amount excreted was estimated on the assumption that the serum concentration had remained constant at its final level throughout the experiment. Deuterium oxide taken by mouth is rapidly

Table $\mathrm{x}$. Deuterium-oxide concentrations in the serum of the subjects at 2, 3 and $4 h$ after they had taken by mouth the stated volumes of deuterium oxide

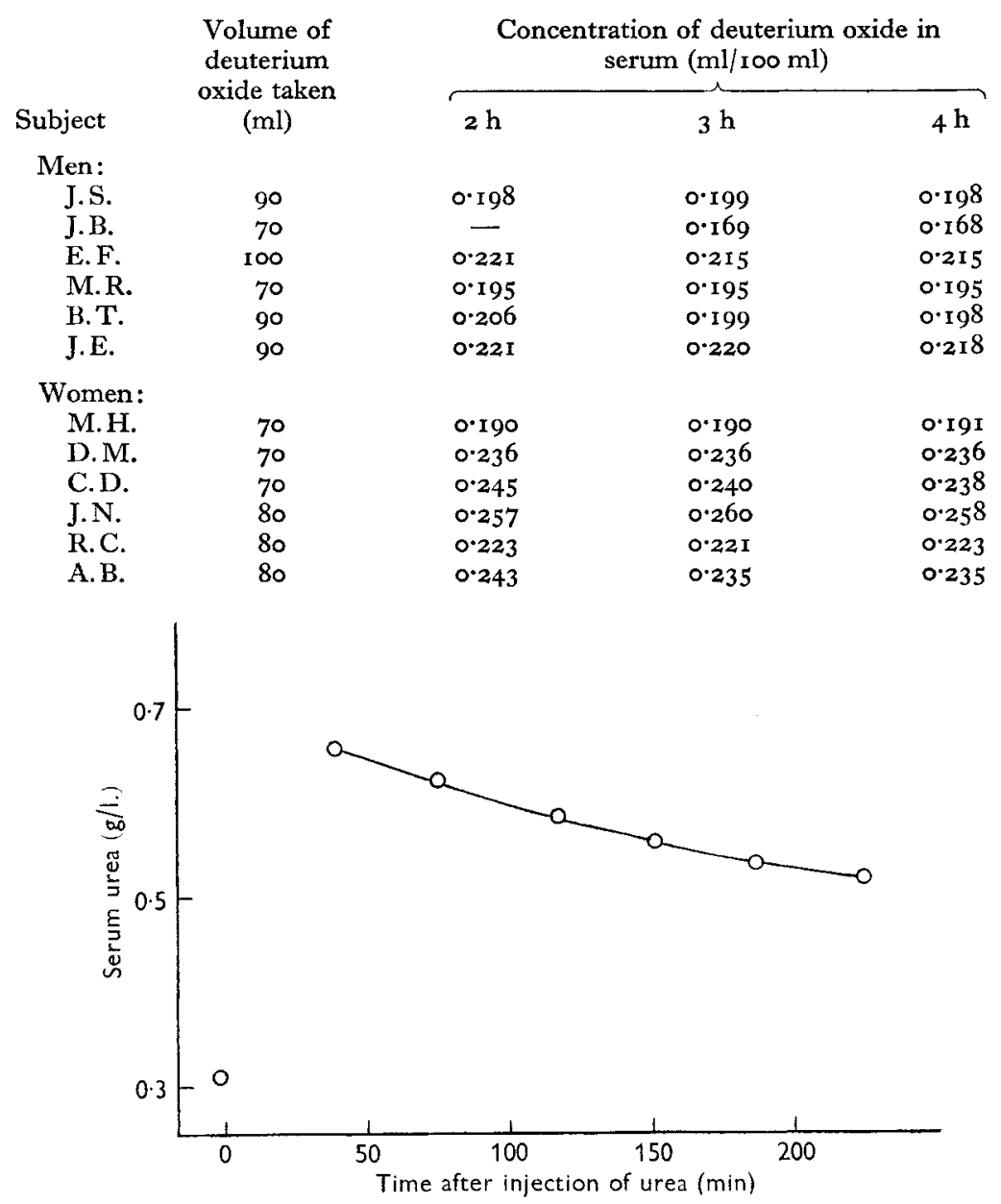

Fig. $r$. Rise and fall of urea concentration $(\mathrm{g} / \mathrm{l}$.) in the serum of a male subject after the intravenous injection of $\mathrm{I} 6.03 \mathrm{~g}$ urea.

absorbed (Schloerb, Friis-Hansen, Edelman, Solomon \& Moore, 1950). Such an assumption will introduce little error in the final result, particularly since diuresis due to the urea was not marked, the mean urinary output for these subjects being $\mathrm{I} 86 \mathrm{ml}$ in the first $2 \mathrm{~h}$ and $103 \mathrm{ml}$ in the second $2 \mathrm{~h}$.

Accuracy of the determinations. The accuracy of the chemical method for urea and of the physical method for deuterium oxide was assessed. Seven $0.2 \mathrm{ml}$ samples of the same serum were analysed for urea. The mean value for the concentration was 
$0.5522 \mathrm{~g} / \mathrm{l}$. with a standard deviation of $0.00 \mathrm{I} \mathrm{g} / \mathrm{l}$. Two $\mathrm{ml}$ of $\mathrm{I} \%$ deuterium-oxide solution were added to $9 \mathrm{ml}$ of normal serum to give an estimated final concentration of $0.193 \mathrm{ml} / 100 \mathrm{ml}$ (water of serum assumed to be $93 \%$ ). The mean value for the concentration found by the method was $0.192 \mathrm{ml} / 100 \mathrm{ml}$ with a standard deviation of $0.0028 \mathrm{ml} / \mathrm{I} 00 \mathrm{ml}$.

Validity of the assumption made in calculating the urea space. Urea was given to a subject in the manner described above, but blood and urine were collected thereafter at $45 \mathrm{~min}$ intervals up to a total of $4 \cdot 5 \mathrm{~h}$. Fig. I shows the rise and fall of the serum

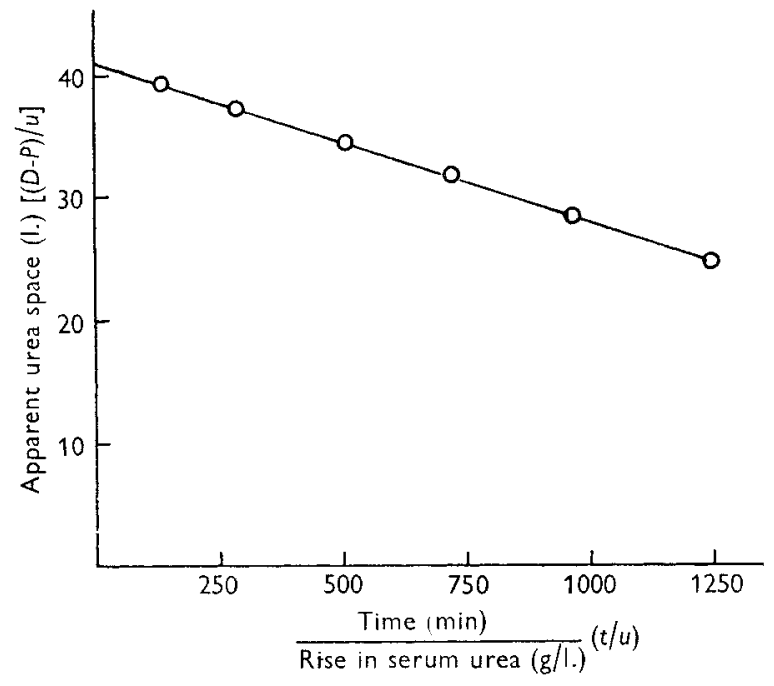

Fig. 2. Variation of the apparent urea space,

$$
\frac{\text { weight of urea injected - weight of urea excreted }(g)}{\text { rise in urea concentration in serum }(\mathrm{g} / \mathrm{l} \text {.) }},
$$

with time $(\mathrm{min})$ rise in urea concentration in serum $(\mathrm{g} / \mathrm{l}$.$) .$

urea in a male subject after intravenous injection. Fig. 2 shows the variation of $(D-P) / u$ with $t / u$. These results indicate that after intravenous injection of urea a steady state is attained surprisingly rapidly, distribution being virtually complete at 45 min. Further, the constancy of the slope of the line in Fig. 2 supports the supposition that the production of urea in the body is constant under these conditions.

\section{RESULTS}

Table 2 shows the ages, heights, weights and urea and deuterium-oxide spaces for each individual. In all subjects except one, the urea space was smaller than the deuterium-oxide space. The difference for the males varied between +0.4 and $-8.0 \%$ with a mean of $-3.6 \%$, and for the females between -2.5 and $-11.0 \%$ with a mean of $-7.0 \%$. The probability of this sex difference arising by chance is between 0.05 and $\mathrm{O}^{\prime} \mathrm{I}$. The overall mean for the difference between the urea and deuterium-oxide spaces was $-5.3 \%$. 
Table 2. Deuterium-oxide and urea spaces determined simultaneously in six men and six women

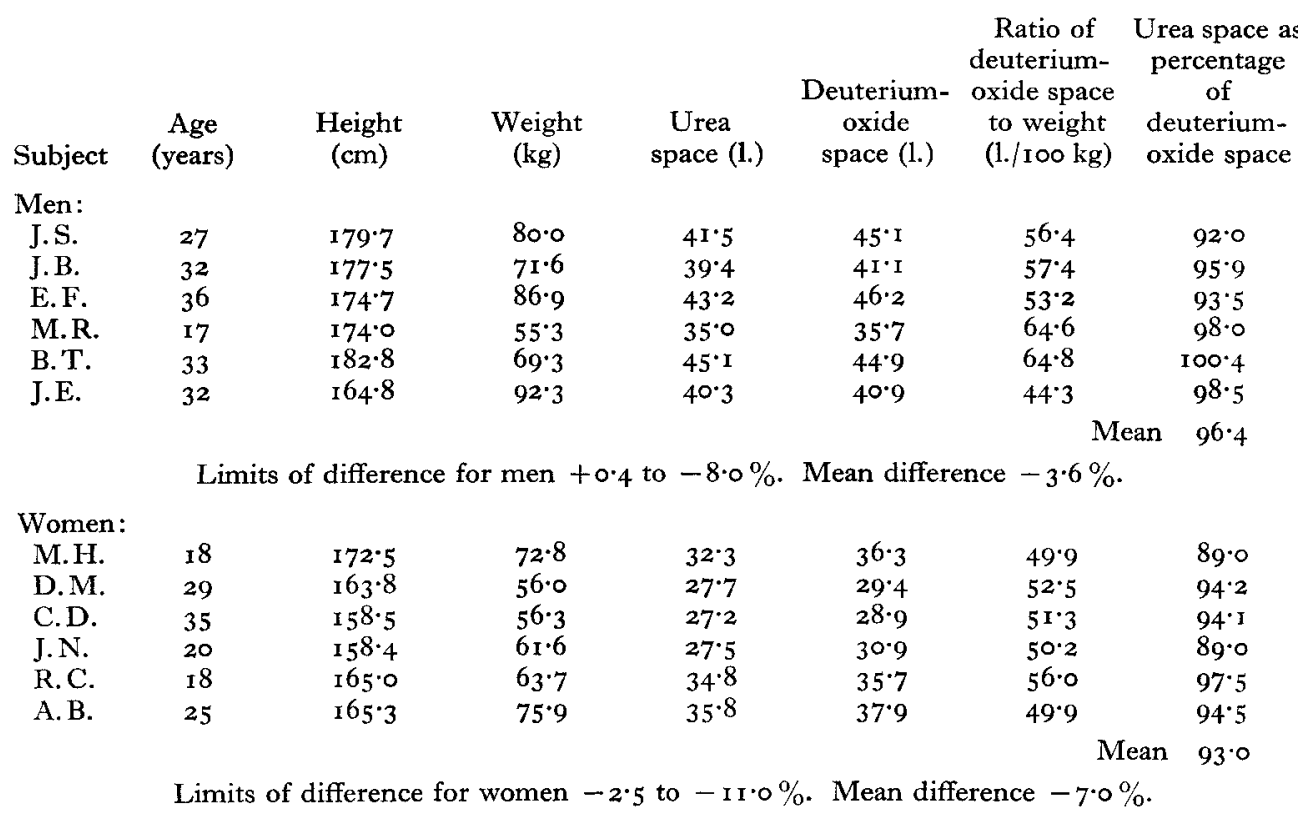

\section{DISCUSSION}

The antipyrine space has been shown to be smaller than the deuterium-oxide space (Ljunggren, 1955) and the urea and antipyrine spaces to be of about the same size (Srikantia \& Gopalan, 1957), and my results agree with these observations. Part of the explanation probably is that there are parts of the body in which urea never equilibrates at unity in the tissue water, or else takes a long time to reach an equilibrium. Tissues of which this is known to be true are the central nervous system and cerebrospinal fluid (Conway \& Fitzgerald, I942; Schoolar, Barlow \& Roth, I960; J. Stubbs, I960, personal communication). There may be other elements of the tissue water to which it also applies. Another factor is that deuterium atoms from the deuterium oxide will exchange with certain hydrogen atoms of organic molecules. Hence the deuterium will be diluted into a volume larger than that of the body water alone. It has been estimated that the total quantity of exchangeable hydrogen is $0 \cdot 5-1 \cdot 5 \%$ of the body-weight greater than that of the hydrogen of the body water (Schloerb et al. I950). In other words, the deuterium-oxide space is $\mathrm{I}-3 \%$ larger than the total body water.

That the mean difference between the two spaces was bigger for the female group than for the male is probably significant. No satisfactory explanation can be suggested.

An alternative procedure, generally used in the determination of the urea space (McCance \& Widdowson, I95I; Pawan, 1954) is to determine the production of urea in the body by collecting one or two hourly control specimens of urine before the beginning of the test. This procedure appears to introduce greater and uncon- 
trollable errors because, if the urine flow and therefore the urea clearance is changing, the excretion of urea will not represent production, nor will degradation in the gut be allowed for (Walser \& Bodenlos, 1959).

The use of urea given intravenously provides a safe and relatively simple means of determining total body water. The values obtained are probably less than the true body water and subject to moderate error, inherent in the nature of the exchanges of urea in the body. The reproducibility of the method in the same subject has not been studied, since it is almost impossible in such studies to distinguish between true changes in body water and errors in the method. However, it does not seem likely that the urea method is sufficiently sensitive to measure changes in body water in one subject over a period.

Unpleasant side-effects noted after the intravenous injection of urea by other workers were probably due to breakdown products of urea formed after autoclaving solutions or after allowing them to stand. The only untoward reactions in my subjects were a painless sterile thrombosis in the vein injected in one and a mild pyrexial reaction in another.

\section{SUMMARY}

I. A method of determining the volume of distribution of urea after intravenous injection, by extrapolation to zero time, is presented.

2. The urea space was compared with deuterium-oxide space determined at the same time in six men and six women. In all the subjects except one, the urea space was less than the deuterium-oxide space, the mean overall difference being $5 \cdot 3 \%$.

This work is the first of a series of investigations in a programme on body composition initiated by Mr J. R. P. O'Brien.

I should like to thank Miss M. Hudson for technical assistance, Baxter Laboratories Ltd for providing the urea for intravenous injection and all the subjects for cheerful co-operation. I am also most indebted to Dr P. C. Mallam and Dr J. Stubbs for helpful criticism and advice.

\section{REFERENCES}

Cohn, M. (1946). In Preparation and Measurement of Isotopic Tracers. [D. Wright Wilson, A. O. C. Nier and S. P. Reimann, editors.] Ann Arbor, Michigan: J. W. Edwards.

Conway, E. J. ( I 947). Microdiffusion Analysis and Volumetric Error, and ed. London: Crosby Lockwood and Son Ltd.

Conway, E. J. \& Fitzgerald, O. (r942). F. Physiol. ror, 86.

Eggleton, M. G. (1951). Ұ. Physiol. 115, 482 .

Ljunggren, H. (1955). Acta physiol. scand. 33, 69.

McCance, R. A. \& Widdowson, E. M. (195I). Proc. roy. Soc. B, 138, Ir5.

Pawan, G. L. S. (1954). Arch. Middx. Hosp. 4, I 19.

Schloerb, P. R., Friis-Hansen, B. J., Edelman, I. S., Sheldon, D. B. \& Moore, F. D. (195 1). F. Lab. clin. Med. 37, 653.

Schloerb, P. R., Friis-Hansen, B. J., Edelman, I. S., Solomon, A. K. \& Moore, F. D. (1950). F. clin. Invest. 29, 1296.

Schoolar, J. C., Barlow, C. F. \& Roth, L. J. (1960). F. Neuropath. 19, 2 16.

Srikantia, S. G. \& Gopalan, C. (1957). Lancet, 273, I037.

Steffensen, K. A. (1947). Acta physiol. scand. 13, 282.

Walser, M. \& Bodenlos, L. J. (1959). F. clin. Invest. 38, I6r7. 